\title{
GEOLOGY
}

UDC 553.07

M.A. Mizernaya ${ }^{1}$, Cand. Sc. (Geol.-Min.), orcid.org/0000-0001-8618-7352,

A. P. Miroshnikova ${ }^{2}, \mathrm{PhD}$, orcid.org/0000-0002-2710-7049, A. P. Pyatkova ${ }^{1}$, orcid.org/0000-0001-5974-9698, A. T. Akilbaeva ${ }^{1}$, orcid.org/0000-0002-6093-8530 https://doi.org/10.29202/nvngu/2019-5/2

1 - D. Serikbayev East Kazakhstan State Technical University, Ust-Kamenogorsk, the Republic of Kazakhstan, e-mail: mizernaya58@bk.ru

2 - "VNIItsvetmet", Affiliate of RSE "NC CPMRM RK", Ust-Kamenogorsk, the Republic of Kazakhstan, e-mail: anastasiya-2588@mail.ru

\section{THE MAIN GEOLOGICAL-INDUSTRIAL TYPES OF GOLD DEPOSITS IN EAST KAZAKHSTAN}

Purpose. To characterize leading geological-industrial types of gold deposits within Kazakhstani part of the Great Altai.

Methodology. Field studies are within proper gold ore and ore-bearing deposits. Sampling is carried out for defining chemical composition and regularities of basic ore minerals and impurities distribution. Microprobe analysis by using a scanning election microscope JSM 6390LV, comparative analysis of ore mineralization were applied at the studied deposits.

Findings. Gold ore deposits of the Great Altai were formed within the period from the end of Riphean to the end of Phanerozoe time in different geodynamic conditions. The most productive ones are $\mathrm{O}_{3}, \mathrm{D}_{1-2}, \mathrm{C}$ and $\mathrm{K}_{2}$ age boundaries. Island arc, ensimatic, ensialic, volcanogenic-sedimentary and collision environments are of great interest for gold mineralization. The most important sources of gold mineralization within the Great Altai are gold-base metals, gold-quartz, gold-sulphide-quartz deposits. Part of medium and small deposits can be transferred to the higher rank after additional evaluation. Moreover, prerequisites for discovering new deposits are far from being exhausted in traditional ore mining regions. Complex gold-base metals (polymetallic and copper-lead-zinc) deposits of Rudny Altai belt also have high content of associated gold and silver.

Originality. The research novelty is in using of highly precise methods for studying ores and host rocks that can be used for the development of low-cost technologies for qualitative evaluation of gold ore deposits that were formed in different geodynamic conditions and time intervals on the basis of mineralogical sampling method, topo-mineralogy method, which enables one to solve the task of replenishing mineral-raw materials of precious metals in Kazakhstan.

Practical value. For the last 15 years there has been a clear tendency towards increase in the world demand and gold production. Although the world gold reserve base features abundant types of deposits, development of gold mining has slowed down in Kazakhstan since 1990-s due to depletion of the richest and favorable deposits, decrease in gold raw material quality, and increase in negative impact on the environment. Extra study on the known gold ore objects, search for gold deposits from the aspect of integrated development imply the aim of overall accounting of basic and secondary components when all the stages of operation are carried out - ranging from geological-estimating and to operational exploration. Nowadays, up-to-date technologies of concentration, and development methods enable to refer these deposits to the objects of primary commercial exploitation. Their studying has scientific value in the issues of endogenetic mineralization and creates prerequisites of discovering new perspective areas and deposits in Kazakhstan.

Keywords: metallogenic specialization, Ore Belt, gold deposits, Central Asia, Great Altai, Kazakhstan

Introduction. According to the generally accepted concept $[1,2]$, basic geological structures of the Great Altai are located in the north [west of the Central Asian mobile belt. They are separated by deep-seated faults of north-west direction from Caledonian structures of the Gorny Altai (by LoktevskoKarairtysh fault in the north-east) and from Chingiz-Tarbagatai by Chingiz-Saur fault (in the south-west) [3, 4].

According to metallogenic zoning inside of the GA the following ore belts are distinguished in geologic structures of the GA within East Kazakhstan: gold-copper-polymetallic (Rudny Altai); rare metal (Kalba-Narym); gold ore (West Kalba); multimetal (Zharma-Saur). Their total length is more than $1000 \mathrm{~km}$ whereas their average width is $300 \mathrm{~km}$ (Fig. 1) [5, 6].

Commercial mineralization is localized in the Rudny Altai zone that is characterized by high femicity of the section, high

(C) Mizernaya M.A., Miroshnikova A. P., Pyatkova A. P., Akilbaeva A. T., 2019 magma saturation and ore density. Epicenters of ore areas and clusters tend to thickening of metabasalt layer (thickness is $20-24 \mathrm{~km})$ and to ridge-like elevating of surface M $(40-43 \mathrm{~km}$ deep) $[7,8]$.

Basic geological-industrial types of gold ore deposits. There are several industrial types of gold ore deposits in East Kazakhstan. They are both proper gold ore and gold bearing deposits (Table 1). Important sources of gold mining are large $\mathrm{Au}-\mathrm{Cu}-\mathrm{Pb}-\mathrm{Zn}$ deposits of the Rudny Altai structural-formation zone where there are high contents of $\mathrm{Au}, \mathrm{Ag}$, rare and rare earth elements (Cd, Se, Re, etc.), along with base metals. The deposits are genetically related to the group of Devonian basalt-andesite-rhyolite formations that build up several productive stratolayers, and the most ore-bearing of them are Emsian, Eifelian, and Givetian. Multi-intermittency of formation and multi-deck distribution of ore mineralization are characteristic within ore zones, ore clusters, and fields. Vertical length of ore mineralization is up to $1500 \mathrm{~m}$ [9]. Ore was 


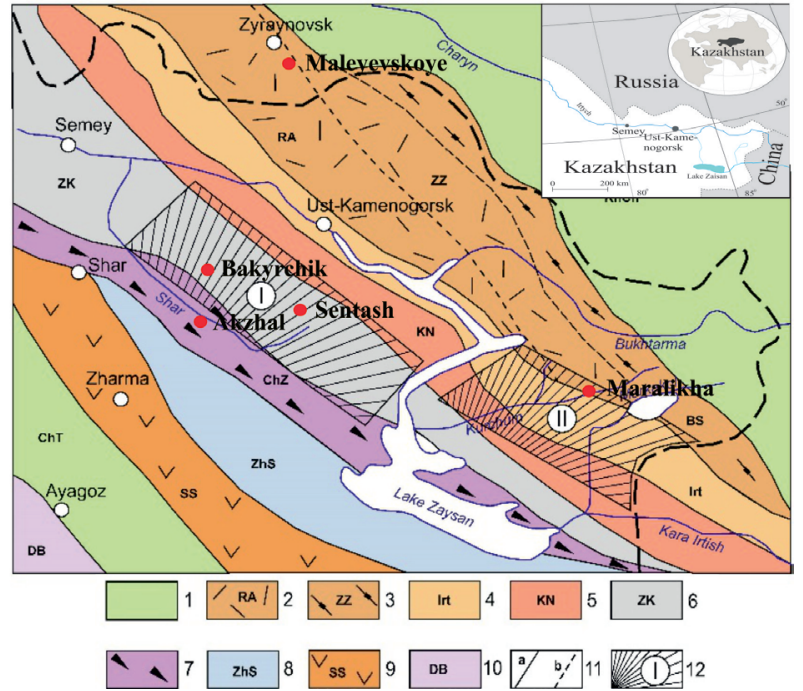

Fig. 1. Tectonic scheme of Kazakhstan part of the GA 1 - Caledonian structural zones of the GA (ChT - Chinghiz-Tarbagatay; KhCh - Kholzunsko-Chuiskaya):

2-9 - structural zones of the Hercynian consolidation area: $2-$ Beloubinsko-Sarymsaktinskaya - BS; 3-Rudno-Altaiskaya - RA (subband - Zmeinogorsko-Zyryanovskaya - ZZ); 4 - Irtyshskaya - Irt; 5 - Kalba-Narymskaya (KN); 6-Zapadno-Kalbinskaya-ZK; 7-Charsko-Zimunaiskaya-ChZ; 8-Zharma-Saurskaya-ZhS; 9-Seriktas-Sarsazanskaya - SS; 10 - DzhungaroBalkhashskaya folded system - DB; 11 - borders of folded zones

formed under submarine conditions, evidently when there was ascending vadose-hydrothermal system of solutions with juvenile spring of metals ( $\mathrm{Fe}, \mathrm{Cu}, \mathrm{Pb}, \mathrm{Zn}, \mathrm{S}, \mathrm{Au}, \mathrm{Ag}$, etc.) and dissolved gases $\left(\mathrm{CO}_{2}, \mathrm{~N}_{2}, \mathrm{H}_{2} \mathrm{~S}, \mathrm{~S}, \mathrm{Cl}\right.$, etc. $)[10,11]$. There are two types of ores according to the way of formation:

Stratiform (volcanogenic-sedimentary) ores are characterized by accumulation of ore matter at the bottom of basin where bedded-rhythmic-laminated ores occur (deposits: Ridder-Sokolnoye, Verh-Ubinskoye, Nikitinskoye and others);

- Hydrothermal-metasomatic is connected with the change in volcanogenic-sedimentary rocks and fluid-porphyritic complexes on the way of ore-bearing flows movement.

The last type includes most commercial sulphide-polymetallic deposits (Zyryanovskoye, Maleyevskoye, Beloussovskoye and others).

There is deposit confinedness to Devonian ring volcanic arcs. Besides sulphide-polymetallic ore mineralization is associated with subvolcanic porphyrites. Porphyritic bodies are the most ore-bearing. They are located in frontal parts of fluid-magmatic flows of Devonian geochronological level.

Metasomatic criteria of ore formation. Hydrothermal metamorphism is of great importance. Propylitization, beresitization, and albitization are widely manifested in ore bearing terrigenous rocks and in partially intrusive rocks of proper gold ore deposits. There are both early areal and syn-ore alterations of host rocks. The first ones go before gold ore mineralization, and form zonal areolas often with arsenic, rare elements, and sulphides gain. Syn-ore alteration is expressed locally in the form of margins on the contact with quartz veins and sulphide containing zones in intrusive and terrigenous rocks.

Gold-copper-polymetallic deposits of the Rudny Altai zone are formed by hydrothermal-sedimentary and hydrothermal-metasomatic ways. The beginning of ore process goes along with formation of hydrothermally altered rocks in orelocalized structure. The content of ore mineralization depends on the degree of hydrothermal alternations of host rocks and character of metasomatosis. As hydrotherms gain potassium, sericites are formed mainly with lead and precious metals. When iron and magnesium are gained, chlorites are formed that go along with copper and iron.
In this area there is close positional connection of sulphide-polymetallic (hydrothermal-metasomatic) ore mineralization with porphirites, especially in the zones of their thinning. It should be taken into account during prognostic-exploration operations [12].

The largest deposits of the Rudny Altai are positioned in multilayers of ore-localized horizons, which indicates pulse character of geothermal solutions. The thickest deposits of solid polymetallic ores were formed above output of gas-hydrothermal solutions (Ridder-Sokolnoye, Maleyevskoye, Artemyevskoye deposits). Places of hydrotherms output on the seabed are fixed as dome-lensoid formations with mineralogical and geochemical deposition zoning manifested by alteration of vertical texture features, and by mineralogical and chemical ore composition.

There are three groups of deposits according to the level of $\mathrm{Au}$ and $\mathrm{Ag}$ accumulation:

1. Deposits with high content of $\mathrm{Au}(1-5 \mathrm{~g} / \mathrm{t})$ and medium content of $\mathrm{Ag}$ (20-85 g/t) - Ridder-Sokolnoye, Novo-Leninogorskoye, Tishinskoye, Dolinnoye.

2. Deposits with low-medium content of $\mathrm{Au}(0.3-1.3 \mathrm{~g} / \mathrm{t})$ and medium-high content of $\mathrm{Ag}(35-120 \mathrm{~g} / \mathrm{t})$ - Irtyshskoye, Artemyevskoye, Maleyevskoye, Orlovskoye, Nikolayevskoye and others.

3. Deposits with low $\mathrm{Au}$ and $\mathrm{Ag}$ content $(0.2-0.5 \mathrm{~g} / \mathrm{t}$ and 10-20 g/t respectively) - Grehovskoye, Chekmar, Putintsevskoye and others. The basic resource of precious metals is concentrated in deposits of the first and second groups.

The Rudny Altai type and its technogenic products contain a wide range of secondary impurities $(\mathrm{Cd}, \mathrm{Se}, \mathrm{Te}, \mathrm{Tl}, \mathrm{Ga}$, $\mathrm{Ge}, \mathrm{Jn}, \mathrm{Bi}, \mathrm{As}, \mathrm{Sb}, \mathrm{S})$ together with basic components [13]. The Rudny Altai type of deposits provides $50-60 \%$ of annual gold mining from subsurface resources of Kazakhstan.

Maleyevskoye deposit is situated in Zyryanovsk ore region of Leninigorsk-Zyryanovsk subband of the Rudny Altai structural formation zone. Accumulations of Devonian and Lower-Carbonian ages, quartz-feldspar porphyries and porphyrites of Middle-Devonian age, porphyrites of Lower-Carbonian age take place in structure of the deposit. Accumulations of Devonian age are presented by Revnyushinskaya $\left(D_{1} e-\right.$ $\left.D_{2} e f_{1} r v\right)$, Maslyanskaya $\left(D_{2} e f_{2}-z v_{1} m s\right)$ and Khamirskaya $\left(D_{2} z v_{2}-D_{3} h r\right)$ suites. Maslyanskaya suite is the main ore-bearing mass (Fig. 2). Polymetallic and pyritic-copper-zinc types of ore are two main technological types on this deposit.

The main ore components are: zinc, copper, lead. Gold, silver, cadmium, bismuth, indium, selenium, tellurium, antimony, arsenic and other elements are present. The increased concentration of gold, silver, cadmium, mercury, bismuth, molybdenum, cobalt, arsenic, antimony, selenium, thallium, tellurium, gallium, indium, germanium, nickel is also noted. Sulphides serve as a carrier and concentrate of passing components (Figs. 2, $a, b, c$ ).

Characteristics of gold deposits. Gold deposits were formed in collision geodynamic conditions (in the Zaisan suture zone) and are located within the West Kalba gold ore belt and the Irtysh shear zone. The following ore types are distinguished: gold-listvenite type; gold-sulphide vein-disseminated type; gold-quartz type; gold-arsenic-carbon-bearing type [14].

Gold-listvenite type occurs in the Irtysh zone (Maraliha deposit). Crystalline schist and amphibolites including serpentinite lenslike mass, dikes of diabase porphyrites and plagiogranite-porphyrites are ore-hosting. Gold-bearing ores were formed in the process of fold-thrust deformations of collision stage and is fixed in ore fold silica-listvenite zones (gold sulphide ore is associated with amphibolite shales). Ore is veindisseminated, basic ore minerals are pyrites, arsenopyrites and gold (Figs. 2, $d, e, f$ ). Chalcopyrite, sphalerite, galenite and fahlore belong to affluent ore minerals. Free and fine-grained gold is in pyrite, arsenopyrite and magnetic iron ore [15].

The gold-sulphide vein-disseminated type belongs to unconventional type of gold ore spatially associated with island-arc, volcanogenic-carbonate-terrigenous formation C1v2-3 (Suz- 
Main types of economic gold deposits

\begin{tabular}{|c|c|c|c|c|}
\hline Ore zone & Ore knot & Ore field & Metalgenius & Deposits \\
\hline \multicolumn{5}{|c|}{ Rudny Altai } \\
\hline Leninogorsko-Zyryanovskoye & Leninogorsko- Zyryanovsku & $\begin{array}{l}\text { Leninogorskoye } \\
\text { Maleyevskoye }\end{array}$ & $\mathrm{Pb}, \mathrm{Zn}, \mathrm{Cu}, \mathrm{Au}, \mathrm{Ag}$ & Ridder-Sokolnoye, Maleyevskoye \\
\hline Orlovsko-Belousovskoye & Atremyevsky, Nikolaevsky & $\begin{array}{l}\text { Atremyevsky, } \\
\text { Nikolaevsky }\end{array}$ & $\mathrm{Cu}, \mathrm{Zn}, \mathrm{Pb}, \mathrm{Au}, \mathrm{Ag}$ & $\begin{array}{l}\text { Tishinskoye, Nikolaevskoye, } \\
\text { Artemyevskoye }\end{array}$ \\
\hline Sekisovskoye & Tserkovsko- Sekisovsky & Sekisovskoye & $\mathrm{Au}, \mathrm{Ag}, \mathrm{Te}, \mathrm{Bi}$ & Sekisovskoye \\
\hline \multicolumn{5}{|c|}{ Yuzhny Altai } \\
\hline Maralikhinskaya & & Maralikhinskoye & $\mathrm{Au}, \mathrm{As}, \mathrm{Hg}$ & Maralikha, Manka, Kystav-Kurchum \\
\hline \multicolumn{5}{|c|}{ Charsko-Zimunaysky metalgenic zone } \\
\hline Gornostayevskaya & & & $\mathrm{Ni}, \mathrm{Co}, \mathrm{Hg}, \mathrm{Au}$ & Gornostayevskoye \\
\hline Kempirskaya & Zhanan-Kempirsky & & $\mathrm{Au}, \mathrm{Ag}$ & Camper, Zhanan \\
\hline \multirow{2}{*}{$\begin{array}{l}\text { Suzdalsko- } \\
\text { Arkalykskaya }\end{array}$} & Arkalykskoye & & $\mathrm{Au}, \mathrm{Ag}$ & Severny Arkalyk \\
\hline & Suzdalskoye & & $\mathrm{Au}, \mathrm{As}$ & Suzdal, Maycheku, Zhaym \\
\hline Charskaya & & & $\mathrm{Cr}, \mathrm{Ni}, \mathrm{Co}, \mathrm{Hg}, \mathrm{Au}$ & Belogorskoye \\
\hline \multirow[t]{3}{*}{ Akzhal-Boko-Zaysanskaya } & Akzhal-Boko & & $\mathrm{Au}, \mathrm{As}$ & Akzhal, Boko, Vasilyevskoye \\
\hline & Ashaly & Ashaly & $\mathrm{Au}, \mathrm{As}$ & Yuzhnye Ashaly \\
\hline & Koytas & Koytas & $\mathrm{W}, \mathrm{Sn}, \mathrm{Au}, \mathrm{Sb}$ & Suurly \\
\hline \multicolumn{5}{|c|}{ Zapadno- Kalbinskaya metalgenic zone } \\
\hline \multirow[t]{2}{*}{ Mukursky } & Семейтау & Zherek & $\mathrm{Au}, \mathrm{As}, \mathrm{Sb}$ & Zherek \\
\hline & Kedey & Kedey & $\mathrm{Au}, \mathrm{Ag}, \mathrm{As}$ & Kedey, Central Mukkur \\
\hline \multirow{8}{*}{ Bakyrchiksky } & \multirow[t]{2}{*}{ Baygorinsky } & Baygora & $\mathrm{Au}, \mathrm{As}$ & Baygora I \\
\hline & & Miyaly & $\mathrm{Au}, \mathrm{Ag}, \mathrm{As}$ & Miyaly \\
\hline & Espe & Espe & $\mathrm{Au}, \mathrm{Ag}$ & Espe \\
\hline & Sarytau & Sarytau & $\mathrm{Au}$ & Sarytau, Dymovka \\
\hline & Bakyrchik & \multirow[t]{3}{*}{ Bakyrchikskoye } & $\mathrm{Au}, \mathrm{Ag}, \mathrm{As}, \mathrm{Sb}$ & Bakyrchik, Bolshevik \\
\hline & Kanaysky & & $\mathrm{Au}, \mathrm{As}$ & Kanayka \\
\hline & Kazanchunkur & & $\mathrm{Au}, \mathrm{Ag}, \mathrm{As}$ & Kazanchunkur \\
\hline & Zhanatas & Zhanatas & $\mathrm{Au}, \mathrm{As}$ & Zhanatas \\
\hline \multirow[t]{5}{*}{ Kuludzhunsky } & Sentash & Sentash & $\mathrm{Au}$ & Sentash \\
\hline & Dzhumba & Dzhumba & $\mathrm{Au}, \mathrm{As}$ & Dzhumba, Zaninskoye \\
\hline & \multirow[t]{3}{*}{ Kuludzhun } & Terekty & $\mathrm{Au}, \mathrm{As}$ & Terekty \\
\hline & & Kuludzhun & $\mathrm{Au}, \mathrm{As}, \mathrm{Sb}, \mathrm{Hg}, \mathrm{W}$ & Kuludzhun \\
\hline & & Laily & $\mathrm{Au}, \mathrm{As}, \mathrm{W}$ & Laily \\
\hline Baladzhalsky & Baladzhal & Baladzhal & $\mathrm{Au}, \mathrm{As}$ & Baladzhal, Marinovskoye \\
\hline
\end{tabular}

dalskoye, Akzhal, Zhaima and others). Geological-genetic model of ore formation is defined as hydrothermal-metasomatic and determined by formation of gold-bearing crushed vein and jasperoids in tectonically fractured carbonate- terrigenous rocks. Auriferous ore stratum was formed as a result of minor intrusions, plagiogranite dikes and granodiorites (Knushsky complex $\mathrm{C}_{3}$ ). Ore bodies are represented by crushed veins, interlacing veins, and quartzitic veins with pyrites, arsenopyrite, rarely with antimonite. Free gold is fine and submicroscopic (average content is $8-10 \mathrm{~g} / \mathrm{t}$ ) [16]. Ores are related to Carlinstyle deposit type according to basic characteristics. These deposits are being developed as they are of economic interest.

Akzhal gold-sulphide vein-disseminated deposit. Volcanogenic terrigenous rocks of Arkalyk formation of lower-Carboniferous age (porphyrite, jasper, aleurolite, sandstone, siliceous shales with rare lenses of rift limestone) and small intrusions of the Kunush complex $\left(\mathrm{C}_{3}-\mathrm{P}_{1}\right)$ take place in the structure of the deposit.

Pre-ore metasomatism is shown mostly in fault zones enclosing quartz gold bodies. An increase in gold and arsenic occurs in birchites near quartz veins. Gold in berezites is associated with arsenic pyrite. Gold-sulphide-quartz mineralization of the Akzhal deposit is composed by mineralized crushing zones with uneven distribution of sulphides and gold (Figs. 3, $a, b, c$ ).

Ore bodies are represented by gold-bearing quartz veins with free gold and by mineralized zones with thickness up to $1-1.5$ and $100 \mathrm{~m}$, respectively.

Gold-quartz type is characterized by gold-quartz-vein deposits widely represented in West-Kalba zone (Kuludgun, Sentash, Kazan-Chunkur and others). They are spacely located in low carbon graywacke sediments

(Aganaktinskaya suite $\mathrm{C1}_{\mathrm{S}}$ ). Ore is controlled by faulting and is genetically associated with minor intrusions and $\mathrm{Ku}-$ nushsky complex dikes (C3). Ores are characterized by great variety: pyrite, arsenopyrite, gold, chalcopyrite, sphalerite, fahlores, antimonite, scheelite and others [17, 18]. Gold is free in polysulfide and stibial assemblages. The deposits refer to small ones by scale of ore. These deposits are being developed. Besides they are the source of placer gold (Figs. 3, $d, e, f$ ).

Gold-arsenic-carbon-bearing type is presented by larger deposits in terms of gold reserves (Bakyrchik, Bolshevik, Gluboky Log and others) and is formed on middle-Hercynian collision ore-bearing level (C2-C3). Sub-aerial grey molasses, alluvial-limnic and bog carbon-bearing black-shale lithofacies (Bukon suite (C2-3)), subjected to intensive dynamic-meta- 


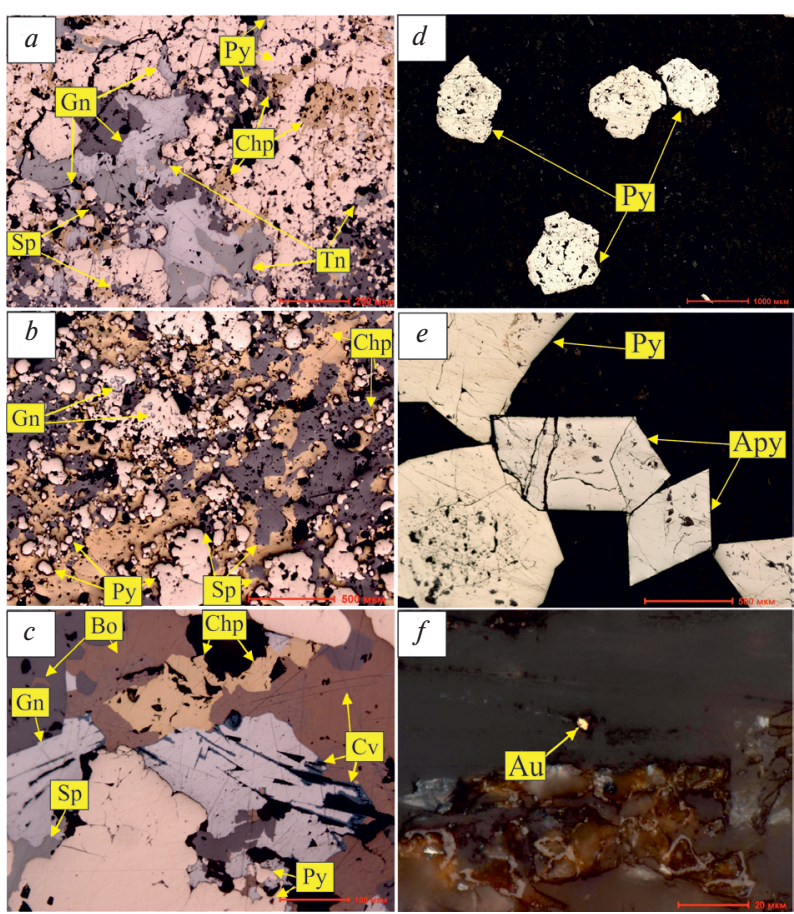

Fig. 2. Mineralization of the Maleyevskoye deposit ( $a, b, c)$ and Maralicha deposit $(d, e, f)$ (chp - chalcopyrite, sp - sphalerite, py - pyrite, apy - arsenopyrite, gn - galena, cvcovelline, bo - bornite, th - tennantite, au - gold)
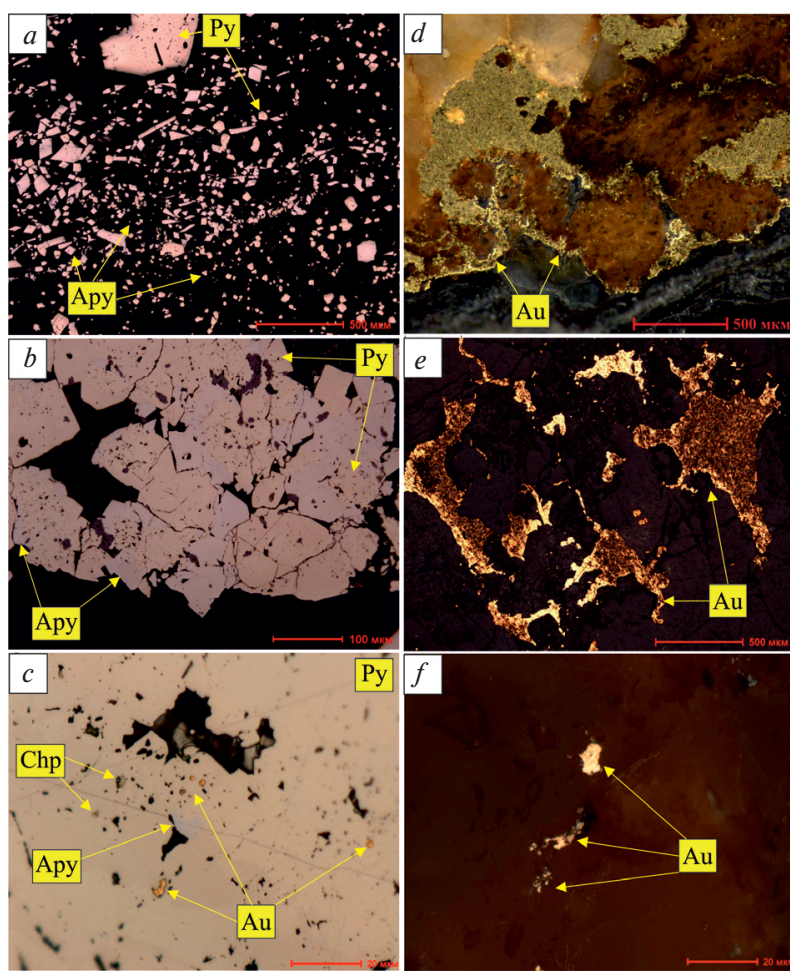

Fig. 3. Mineralization of the Akzhal deposit $(a, b, c)$ and Sentash deposit (d, e, f) (chp - chalcopyrite, py - pyrite, apy - arsenopyrite, au - gold)

morphic and hydrothermal-metasomatic changes (zone of the Kyzylovsky deep-seated fault), and to the influence of deep seated $(3-5 \mathrm{~km})$ rock bodies.

Gold ore deposits in carboniferous volcanogenic-carbonate-terrigene formation make up considerable share of the world gold reserves. Large objects are known in the USA, Australia, Russia, China, Kazakhstan and other regions of the world [19].
Bakyrchik deposit is located in East Kazakhstan region in the north-west of the central part of the Kalba structural-facial zone of Zaisan fold system. Together with minor deposits and ore occurrences, distributed in the Kyzylovsky zone or in its plan-parallel splays, it forms a single the Bakyrchik-Bolshevik ore field. The Kyzylovsk zone is understood as a complex, long-lived structure that develops in the side part of the basin at the boundary of sediments of Arkalyk and Bukon formations and hosts dykes and mineralization. In the contemporary view, the geological structure of the sedimentary section within the Bakyrchik ore field is represented as follows [20].

Analysis of geologic conditions for forming deposit Bakyrchik proves complicated history of gold accumulation and concentration in ores of gold-arsenic-carbon-bearing type. Ore bodies of the deposit are represented by mineralized zones of banded, phacoidal and tabular shapes of considerable thickness (up-to 10-20 m) and more than 1.0-1.2 km deep. Basic ore-control elements are failure frames of north-west and sublatitudinal direction (overthrusting, shift-upthrow fault), lithological composition of reservoirs and magmatic formations (granitoid mass hidden in depth of 3.0-3.5 km and dikes of marmorate compound noted in the zone of ore-bearing reverse).

Ore minerals of Bakyrchik deposit form five paragenetic assemblages: early melnicovite-pyrites-pyrrhotine-marcasite (with nickeline and pentlandite); ore gold-pyrite-arsenic pyrite (with cubanite and gersdorffite), gold-quartz-polymetallic (fahlore, chalcopyrite, galenite, and sphalerite), and goldquartz-carbonate-scheelite-chalcopyrite (with breunnerite, dolomite, aikinite, free gold); late quartz-carbonate-antimonite-tetrahedrite (with marcasite, remanie gold). Gold-pyritearsenic pyrite assemblage have "through" expansion, melnicovite-pyrites-pyrrhotine-marcasite melnicovite-pyrites-pyrrhotine-marcasite and gold-quartz-carbonate-scheelite-chalcopyrite are developed at deep levels, gold-quartz-polymetallic and quartz-carbonate-antimonite-tetrahedrite are inclined to upper and medium horizons. Impregnated and vein-impregnated gold-pyrite-arsenic pyrite assemblage association is the most significant $(90 \%)$ in total mass of silphides and total gold balance (Fig. 4).

Carbon-bearing, sericitic, kaolinite-hydromica, quartz-sericitic, sericite-phlogopite-carbonate, chlorite-albite and other metasomatic associations are developed at the deposit [19].

Ore bodies are represented by phacoidal and taenioid deposits with abundant impregnations of gold-bearing pyrite and arsenopyrite. The thickness is $0.6-20 \mathrm{~m}$, flat deposits are reaching $1700 \mathrm{~m}$ to the dip. Basic ore minerals are pyrite, arsenopyrite and gold, secondary minerals are antimonite, pyrrhotite, marcasite, chalcopyrite, galenite and others. Gold is hard to recover and its content ranges from 0.2 to $60 \mathrm{~g} / \mathrm{t}$, average is $8-9 \mathrm{~g} / \mathrm{t}$. Considerable part of gold is found in carbonaceous compounds. Fullerene and fullerene-shaped precipitates, micro- and nanoparticles, nanotubes containing $\mathrm{Au}, \mathrm{Ag}$, $\mathrm{Pt}, \mathrm{Pd}, \mathrm{W}, \mathrm{Mo}, \mathrm{Sn}, \mathrm{Y}, \mathrm{Yb}, \mathrm{Ta}$ and other elements were determined by using scanning election microscope (SEM). The considered type is leading in prospected reserves and forecast resources among gold ore deposits of Kazakhstan.

Conclusions. The lithologic-and-stratigraphic factor is of great importance in defining gold control with distinguishing geochronological levels and sediments of increased carbonaceousness that are favourable for sedimentation and concentration of gold. All ore fields and deposits have magmatic control of gold ore that is genetically related to hypabyssal minor intrusions and dikes of collision geodynamic conditions. Geological-structural, geophysical and mineralogical-geochemical, prognostic-prospecting criteria and results of geologicalgenetic modelling of ore objects were taken into account, and on their basis the evaluation of the studied region perspectives was carried out (Seltmann et al. 1994, 2007).

Acknowledgements. The work was sponsored by grants N 36-26-18 of MES of Kazakhstan Republic (2018-2020). 


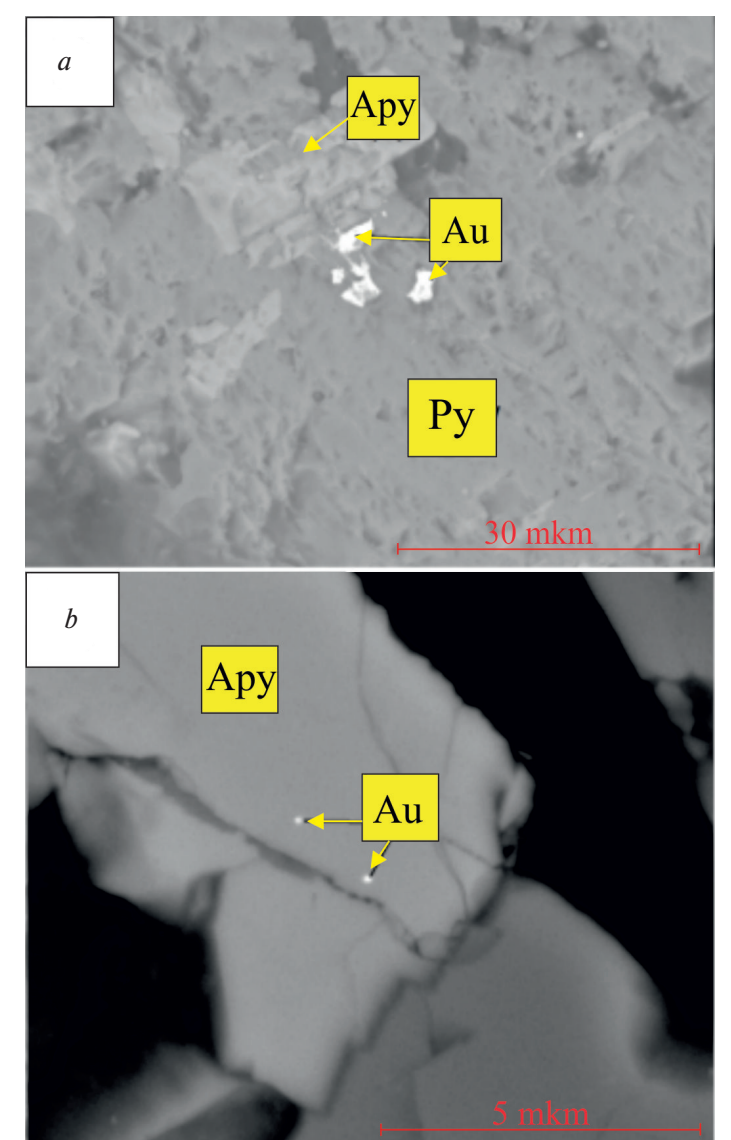

Fig. 4. Mineralization of the Bakyrchik gold deposit ( $p y-p y$ rite, apy - arsenopyrite, au - gold)

References.

1. Seravkin, I. B., \& Kosarev, A. M. (2019). Southern Urals and Rudny Altai: A Comparative Paleovolcanic and Metallogenic Analysis. Geology of Ore Deposits, 61(2), 99-117. DOI: 10.1134/S1075701553081038.

2. Kosarev, A. M., \& Seravkin, I. B. (2018). Tubinsk-Gai belt: regularities in the formation and location of massive sulfide mineralization in the light of new petrological-geochemical data on the composition of ore-bearing complexes. Geologicheskiy Vestnik, (2), 36-57. DOI: 10.31084/2619-0087/2018-2-3.

3. Chekalin, V. M., \& Dyachkov, B.A. (2013). Rudny Altai basemetal belt: localization of massive sulfide mineralization. Geology of Ore Deposits, 55(6), 513-532. DOI: 10.1134/S1075701513060020. 4. Dyachkov, B.A., Ganzhenko, G. D., \& Sapargaliev, E. M. (2016). Geodynamic conditions of the Greater Altai ore-bearing structures formation. Almaty: "KazGeo".

5. Khromykh, S. V., Kotler, P. D., Izokh, A. E., \& Kruk, N. N. (2019). A review of early permian (300-270 ma) magmatism in Eastern Kazakhstan and implications for plate tectonics and plume interplay. Geodynamics \& Tectonophysics, 10(1), 79-99. DOI: 10.5800/GT-2019-10-1-0405.

6. Kuybida, M. L., Krug, N. N., Shokolsky, S.P., Gusev, N.I., \& Murzin, S. P. (2015). Supersubduction plagiogranites of Rudny Altai: age and composition features. Reports of the Academy of Sciences, 464(3), 317-319. DOI: 10.7868/s0869565215270171

7. Kuzmin, M. N., \& Yarmolyuk, V. V. (2017). Biography of the Earth: the main stages of geological history. Nature, 66, 12-25. 8. Khromykh, S. V., Tsygankov, A.A., Kotler, P.D., Navozov, O. V., Kruk, N. N., Vladimirov, A. G., Travin, A. V., ... \& Karavaeva, G. S. (2016). Late Paleozoic granitoidmagmatism of Eastern Kazakhstan and Western Transbaikalia: Plume model test. Russian Geology and Geophysics, 57(5), 773-789. DOI: 10.1016/j.rgg.2015.09.018.

9. Kotlyarov, A. V., Simonov, V.A., \& Safonova, I. Y. (2018). Boninites as a criterion for the geodynamic development of magmatic systems in paleosubduction zones in Gorny Altai. Geodynamics \& Tectonophysics, 9(1), 39-58. DOI: 10.5800/ GT-2018-9-1-0336.

10. Mizernaya, M., Dyachkov, B., Kusmina, O., Mizerny, A., \& Oitseva, T. (2017). Main types of gold deposits of the eastern Kazakhstan. 17th International Multidisciplinary Scientific Geoconference: Surveying Geology and Mining Ecology Management, Albena; Bulgaria, SGEM, 17(11), 299-306. DOI: 10.5593/sgem2017/11/s01.038.

11. Kruk, N. N., Gavryushkina, O.A., Rudnev, S. N., Shokalsky, S. P., Vasyukova, E. A., Kotov, A. B., Sal'nikova, E. B., ... \& Kruk, E.A. (2017). Petrology and age of granitoids of the Aturkol Massif, Gorny Altai: Contribution in the problem of formation of intraplate granitoids. Petrology, 25(3), 318-337. DOI: $10.1134 / \mathrm{S} 086959111703002 X$.

12. Ermolov, P.V., Musina, E.V., \& Portnov, V.S. (2018). Studying the age and composition of the foundation of the Irtysh shear zone in the Kalba-Narym terrane ISSN 15614212, Vestnik EKSTU, (3), 16-20.

13. Gusev, A. I., \& Tabakaeva, E. M. (2015). Gold in the massive sulfide deposits of Rudny Altai. Central Asian Journal of Basic and Applied Research, (4), 41-56.

14. Pak, N.T. (2017). Models of metasomatic zoning of gold deposits, as a method for their predictive assessment. Innovative and promising technologies of geological exploration in $\mathrm{Ka}$ zakhstan: Proceedings of the International Scientific and Practical Conference. Retrieved from http://icite.ukgu.kz/ sites/default/files/archive/Abstract-Book.pdf

15. Mizernaya, M., Dyackov, B., Miroshnikova, A., Mizerny, A., \& Orazbekova, G. (2017). Large sulfide-quartz stockwork gold deposits of Kazakhstan - formation conditions and predicting criteria. Visnyk of Taras Shevchenko National University of Kyiv-Geology, (3), 82-88. DOI: 10.17721/1728-2713.78.10. 16. Mizernaya, M.A., Seltmann, R., Miroshnikova, M.P., Mizerny, A., \& Orazbekova, G. B. (2018). Geological and geochemical models of gold stockwork deposits in intrusive plutons of North and East Kazakhstan. News of the National Academy of Sciences of the Republic of Kazakhstan. Series of Geology and Technical Sciences, (2), 134-140.

17. Kokkuzova, M., Bekenova, G., Dyussembayeva, K., Dolgopolova, A., \& Seltmann, R. (2017). Gold-barite-polymetallic VMS deposit of Maikain, NE Kazakhstan. Applied Earth Science, 126(2), 71-72.

18. Gaskova, O.L., Redin, Y.O., Nevolko, P.A., Kolpakova, M.N., \& Naymushina, O.S. (2018). Physico-chemical modeling of high-temperature stages of gold deposition at the Lugokanskoe deposit (Eastern Transbaikalia). News of Tomsk Polytechnic University. Georesource Engineering, 329(10), 57-66. 19. Dolgopolova, A., \& Seltmann, R. (2015). Mineralogical and Geochemical Characteristics of the Vasilkovskoye Gold Deposit (North Kazakhstan). $13^{\text {th }}$ SGA Biennial Meeting on Mineral Resources in a Sustainable World (pp. 77-80). Nancy, France. DOI: 10.1080/03717453.2016.1166663.

20. Mizerny, A. I., Miroshnikova, A. P., Mizernaya, M., \& Diachkov, B. O. (2017). Geological and structural features, magmatism and mineralization of Sekisovskoe and Vasylkovskoe Stockwork gold deposits (Kazakhstan). Naukovyi Visnyk Natsionalnoho Hirnychoho Universytetu, 2, 5-12.

\section{Провідні геолого-промислові типи золоторудних родовищ Східного Казахстану}

\section{М. О. Мізерна ${ }^{1}$, А. П. Мірошникова ${ }^{2}$, Г. П. Пяткова ${ }^{1}$, А. Т. Акилбаєва ${ }^{1}$}

1 - Східно-Казахстанський державний технічний університет імені Д. Серікбаєва, м Усть-Каменогорськ, Республіка Казахстан, e-mail: mizernaya58@bk.ru

2 - „СНДІколмет“, філія РДП „НЦ КПМС РК“, м. Усть-Каменогорськ, Республіка Казахстан, е-mail: anastasiya-2588@mail.ru 
Мета. Характеристика провідних геолого-промислових типів золоторудних родовищ казахстанської частини Великого Алтаю.

Методика. Польові дослідження в межах власне-золоторудних і золотовмісних родовищ. Відбір проб для визначення хімічного складу й закономірностей розподілу основних рудних мінералів і домішок. Мікрозондовий аналіз з використанням скануючого електронного мікроскопа JSM 6390LV, порівняльний аналіз рудної мінералізації на досліджуваних родовищах.

Результати. Золоторудні й золотовмісні родовища Великого Алтаю формувалися в різних геодинамічних обстановках, починаючи з рифея-фанерозою. Найбільш продуктивними є $\mathrm{O}_{3}, \mathrm{D}_{1-2}, \mathrm{C}$ і $\mathrm{K}_{2}$ вікові рубежі. Найбільший інтерес на золото представляють остноводужна енсиматична, островодужна енсіалічна, вулканогенно-осадова та колізійна обстановки. Одним із головних джерел золота в межах Великого Алтаю є золото-кварцеві, золото-сульфідно-кварцові родовища. Частина середніх і дрібних родовищ за додаткової оцінці може перейти в більш великий ранг, до того ж у традиційних гірничорудних районах далеко не вичерпані передумови виявлення нових родовищ. Комплексні поліметалічні й мідно-свинцево-цинкові родовища Рудноалтайського пояса з високим вмістом супутнього золота та срібла також є дуже перспективними.

Наукова новизна. Новизна досліджень - у використанні сучасних високоточних методів вивчення руд і вміщуючи порід родовищ золота, що можуть бути використані для розробки маловитратних технологій якісної оцінки золоторудних родовищ, які сформувалися в різних геодинамічних обстановках і часовому інтервалі. Роботи проводилися на основі методів мінералогічного картування, топомінералогіi, що дозволить вирішити задачу поповнення мінерально-сировинної бази благородних металів Казахстану.

Практична значимість. За останні 15 років намітилася чітка тенденція до збільшення світового попиту та виробництва золота. I хоча світова золото-сировинна база характеризується великою кількістю різних типів родовищ, у Казахстані розвиток золотодобування, починаючи з 90-х років, було загальмовано внаслідок вичерпання найбільш багатих і сприятливих родовищ, зниження якості золотовмісної сировини й посилення негативного впливу на навколишнє середовище. Довивчення відомих золоторудних об'єктів, пошуки нових родовищ золота з позиції їх комплексного освоєння передбачає постановку задачі різнобічного обліку основних і супутніх компонентів при проведенні всіх стадій робіт, починаючи геолого-оціночними до експлуатаційної розвідки. Сучасні технології збагачення, нові методи розробки дозволяють зараз віднести ці родовища до об'єктів першочергового промислового освоєння. Їх вивчення має наукове значення в питаннях ендогенного рудоутворення та створює передумови виявлення нових перспективних площ і родовищ у Казахстані.

Ключові слова: металогенічна спеціалізація, рудний пояс, золоторудні родовища, Центральна Азія, Великий Алтай, Казахстан

\section{Главные геолого-промышленные типы месторождений золота Восточного Казахстана}

\section{М. А. Мизерная ${ }^{1}$, А. П. Мирошникова ${ }^{2}$, А. П. Пяткова ${ }^{1}$, А. Т. Акылбаева ${ }^{1}$}

1 - Восточно-Казахстанский государственный технический университет имени Д.Серикбаева, г. УстьКаменогорск, Республика Казахстан, e-mail: mizernaya58@bk.ru

2 - „ВНИИцветмет“, филиал РГП „НЦ КПМС РК“, г. Усть-Каменогорск, Республика Казахстан, e-mail: anastasiya-2588@mail.ru
Цель. Характеристика ведущих геолого-промышленных типов золоторудных месторождений казахстанской части Большого Алтая.

Методика. Полевые исследования в пределах собственно-золоторудных и золотосодержащих месторождений. Отбор проб для определения химического состава и закономерностей распределения основных рудных минералов и примесей. Микрозондовый анализ с использованием сканирующего электронного микроскопа JSM $6390 \mathrm{LV}$, сравнительный анализ рудной минерализации на изучаемых месторождениях.

Результаты. Золоторудные и золотосодержащие месторождения Большого Алтая формировались в различных геодинамических обстановках, начиная с рифеяфанерозоя. Наиболее продуктивными являются $\mathrm{O}_{3}, \mathrm{D}_{1-2}$, $\mathrm{C}$ и $\mathrm{K}_{2}$ возрастные рубежи. Наибольший интерес на золото представляют собой остноводужная энсиматическая, островодужная энсиалическая, вулканогенно-осадочная и коллизионная обстановки. Одним из главных источников золота в пределах Большого Алтая являются золото-полиметаллические, золото-сульфидно-кварцевые месторождения. Часть средних и мелких месторождений при дополнительной оценке может перейти в более крупный ранг, к тому же в традиционных горнорудных районах далеко не исчерпаны предпосылки выявления новых месторождений. Комплексные полиметаллические и медно-свинцово-цинковые месторождения Рудноалтайского пояса с высокими содержаниями попутного золота и серебра также являются очень перспективными.

Научная новизна. Новизна исследований - в использовании современных высокоточных методов изучения руд и вмещающих пород месторождений золота, которые могут быть использованы для разработки малозатратных технологий качественной оценки золоторудных месторождений, которые сформировались в различных геодинамических обстановках и временном интервале. Работы проводились на основе методов минералогического картирования, топоминералогии, что позволит решить задачу восполнения минерально-сырьевой базы благородных металлов Казахстана.

Практическая значимость. За последние 15 лет наметилась четкая тенденция к увеличению мирового спроса и производства золота. И хотя мировая золото-сырьевая база характеризуется обилием различных типов месторождений, в Казахстане развитие золотодобычи, начиная с 90-х годов, было замедлено вследствие исчерпания наиболее богатых и благоприятных месторождений, снижения качества золотосодержащего сырья и усиления отрицательного воздействия на окружающую среду. Доизучение известных золоторудных объектов, поиски новых месторождений золота с позиции их комплексного освоения предполагает постановку задачи разностороннего учета основных и попутных компонентов при проведении всех стадий работ, начиная геологооценочными до эксплуатационной разведки. Современные технологии обогащения, новейшие способы разработки позволяют сейчас отнести эти месторождения к объектам первоочередного промышленного освоения. Их изучение имеет научное значение в вопросах эндогенного рудообразования и создает предпосылки выявления новых перспективных площадей и месторождений в Казахстане.

Ключевые слова: металлогеническая специализация, рудный пояс, золоторудные месторождения, Центральная Азия, Большой Алтай, Казахстан

Рекомендовано до публікації докт. геол.-мін. наук Є.М.Сапаргалієвим. Дата надходження рукопису 18.01.19. 